\title{
SOSIALISASI DAN EDUKASI PENCEGAHAN DAN PENANGANAN COVID-19 PADA MASYARAKAT DI DUSUN MBOMBA I DESA GHEO GHOMA KABUPATEN ENDE
}

\author{
Syaputra Artama ${ }^{*}$, Pius Kopong Tokan ${ }^{2}$, Rif'atunnisa ${ }^{3}$, Yustina P. M. Paschalia ${ }^{4}$ \\ 1,2,3,4Poltekkes Kemenkes Kupang, Indonesia \\ *Penulis Koresponsensi, email: syaputraartama@gmail.com
}

\begin{abstract}
Covid-19 has become an endemic outbreak that has hit all regions of the world that began at the end of 2019 in Wuhan City, China. The increase in the number of cases of the disease is very fast, so that its spread affects to various ages from children to the elderly. For this reason, there is a need to strengthen education and socialization for the community on how to prevent and handle Covid-19. The goal is for the public to understand and implement Covid-19 prevention behavior. This strengthening is also a preventive effort in suppressing the spread of Covid-19 transmission. As for the form of activity programs carried out by direct methods of socialization, education to the community, making hand washing pilots for community residents and installing sticker posters that are informative and easily understood by the community in Mbomba I Village Gheo Ghoma Ende Regency. The results of this activity can be seen from the increasing public knowledge about the prevention of Covid-19 and being able to implement Covid-19 prevention behavior quite well. Educational activities and socialization to prevent the transmission of the Covid-19 virus become simple things that need to be done consistently, in order to build community concern in maintaining health, doing a clean and healthy lifestyle, especially in the current pandemic period.
\end{abstract}

\section{Keywords: Socialization, Education, Prevention of Covid-19}

\begin{abstract}
Abstrak. Covid-19 telah menjadi wabah pendemi yang menyerang seluruh wilayah di Dunia yang dimulai sejak pada akhir tahun 2019 di Kota Wuhan, China. Peningkatan jumlah kasus penyakit berlansung sangat cepat, sehingga penyebarannya menyerang hingga ke berbagai usia dari anak-anak hingga lanjut usia. Untuk itu diperlukan adanya penguatan edukasi dan sosialisasi bagi masyarakat akan cara pencegahan dan penanganan Covid-19. Tujuannya agar masyarakat dapat memahami dan menerapkan perilaku pencegahan Covid-19. Penguatan ini juga sebagai upaya preventif dalam menekan penyebaran penularan Covid-19. Adapun bentuk program kegiatan yang dilaksanakan dengan metode lansung melakukan sosialisasi, edukasi kepada masyarakat, pembuatan percontohan cuci tangan bagi warga masyarakat dan melakukan pemasangan poster stiker yang informatif dan mudah dipahami oleh masyarakat di Dusun Mbomba I Desa Gheo Ghoma Kabupaten Ende. Hasil dari kegiatan ini dapat dilihat dari bertambahnya pengetahuan masyarakat tentang pencegahan Covid-19 dan mampu menerapkan perilaku pencegahan Covid-19 dengan cukup baik. Kegiatan edukasi dan sosialisasi pencegahan penularan virus Covid-19 menjadi hal sederhana yang perlu dilakukan secara konsisten, agar dapat membangun kepedulian masyarakat dalam menjaga kesehatan, melakukan pola hidup bersih dan sehat, terutama dalam masa pandemic saat ini.
\end{abstract}

Kata Kunci: Sosialisasi, Edukasi, Pencegahan Covid-19

How to Cite: Artama, S., Tokan, P.K., Rif'atunnisa, R., \& Paschalia, Y.P.M. (2022). Sosialisasi dan Edukasi Pencegahan dan Penanganan Covid-19 pada Masyarakat di Dusun Mbomba I Desa Gheo Ghoma Kabupaten Ende. Mitra Mahajana: Jurnal Pengabdian Masyarakat, 3(1), 24-33. doi: https://doi.org/10.37478/mahajana.v3i1.1520

\section{PENDAHULUAN}

Corona Virus Disease merupakan penyakit yang dikenal dengan Covid-19 telah menjadi wabah pendemi yang menyerang seluruh wilayah di Dunia yang dimulai sejak pada akhir tahun 2019 di Kota Wuhan, China. Peningkatan jumlah kasus penyakit berlansung sangat cepat, sehingga penyebarannya menyerang hingga ke berbagai usia dari anak-anak hingga lanjut usia. Virus ini menyerang sistem pernapasan pada manusia, sehingga penularannya sangat mudah. Peningkatan kasus dan tingginya mortalitas akibat Covid-19 membuat seluruh masyarakat menjadi cemas dan khawatir, bahkan di seluruh dunia telah dilakukan pembatasan dalam aktivitas kepada setiap warga. Virus tersebut dapat menular melalui droplet atau batuk dari orang yang telah terinfeksi oleh virus Covid-19. Namun virus ini juga secara tidak lansung dapat ditularkan melalui sentuhan fisik seperti bersalaman, atau berpegangan tangan, yang tanpa disadari virus dapat masuk kedalam tubuh orang yang sehat saat dia menyentuh mata, hidung 
bahkan mulut mereka (Han et al., 2020). Adapun gejala umum yang biasa timbul dari infeksi Covid-19 yaitu batuk, flu, demam, hingga dengan komplikasi berat seperti sesak nafas yang dapat menyebabkan kematian (Wang et al., 2020).

Kasus dengan konfirmasi Covid-19 yang terjadi di Indonesia juga telah banyak bertambah. Jumlah kasus positif Covid-19 hingga tanggal 01 Oktober 2021 mencapai 4.216.728 kasus dengan jumlah pasien meninggal 142.261 jiwa Penambahan jumlah kasus terkonfirmasi positif Covid-19 terbanyak perhari pada tanggal 15 Juli 2021 bahkan mencapai sebanyak 56.757 kasus (Satuan Tugas Penanganan COVID-19, 2021). Dengan tingginya jumlah kasus tersebut Satuan Tugas Penanganan Covid-19 mengambil langkah tegas dalam memutus rantai penyebaran Covid-19 ini dengan membatasi segala aktivitas masyarakat melalui aturan social distancing dan pembatasan sosial berskala besar (PSBB) serta menekankan kepada masyarakat akan penerapan protokol kesehatan yang ketat. Upaya tersebut juga didukung dengan langkah pemerintah memberikan percepatan pemberian vaksinasi Covid-19 kepada tenaga kesehatan bahkan ke seluruh golongan usia kalangan masyarakat. Vaksin Covid-19 mempunyai banyak manfaat, selain untuk melindungi diri dari paparan virus, juga dapat mengurangi penyebaran virus tersebut (Kemenkes RI Dirjen P2P, 2021).

Menurut Hanoatubun (2020), mengemukakan dampak Covid-19 sangat terasa dari segala aspek dan aktivitas. Hal tersebut dapat terlihat dari adanya penurunan perekonomian dan aktivitas sosial, banyaknya usaha pertokoan yang tertutup, dan meningkatnya angka pengangguran akibat banyak masyarakat yang mengalami pemutusan hubungan kerja. Melihat situasi tersebut banyak dari masyarakat mengalami kesulitan dalam memenuhi kebutuhan pokok untuk keluarga mereka akibatnya desakan tersebut membuat masyarakat menjadi kurang memperhatikan akan dampak penuluran Covid-19. Tuntutan untuk tetap beraktivitas diluar rumah tetap dilakukan tanpa mematuhi aturan protokol kesehatan Covid-19 dari menggunakan masker, mencuci tangan dan menjaga jarak.

Pemutusan penyebaran virus ini tidak cukup hanya dengan pencegahan penularannya saja dari diri sendiri tetapi juga harus dibantu dari berbagai aspek peran mulai dari pemerintah, profesi lain hingga ke masyarakat itu sendiri. Salah satu hal yang dapat dilakukan yaitu dimana masyarakat untuk selalu dituntut memiliki imunitas tubuh yang baik agar dapat memerangi risiko penyebaran virus Covid-19 (Amalia \& Hiola, 2020). Peningkatan imunitas tubuh bisa dengan mengonsumsi makanan yang bergizi, komsumsi vitamin, pemanfaatan energi matahari di pagi hari dan aktivitas ringan selama beberapa menit, serta ikut berpartisipasi dalam melakukan vaksinasi (Kemenkes RI, 2021a).

Salah satu daerah terdampak Covid-19 yang menjadi perhatian yaitu daerah Kabupaten Ende Provinsi Nusa Tenggara Timur, Kasus terkonfirmasi Covid-19 hingga mencapai tanggal 27 Desember 2021 telah mencapai 64.237 kasus terkonfimasi Covid-19 dengna jumlah kasus meninggal sebanyak 1.347 jiwa (Satuan Tugas Penanganan COVID-19, 2021). Upaya pemerintah daerah provinsi Nusa Tenggara Timur dalam mencegah penyebaran Covid-19 telah mengeluarkan Peraturan Gubernur No.26 Tahun 2020 tentang Pedoman Tatanan Normal Baru di Provinsi Nusa Tenggara Timur (Pemprov NTT, 2020). Upaya tersebut juga penting untuk menjadi perhatian dan diterapkan di salah satu desa di Kabupaten Ende Provinsi Nusa Tenggara Timur yaitu desa Gheo Ghoma. Salah satu dusun pada desa tersebut dusun Mbomba I belum pernah terdapat pasien dengan terkonfimasi Covid-19, namun dari pengamatan penerapan peraturan tentang adaptasi kebiasaan baru berupa pelaksanaan pembatasan aktivitas social dan penerapan protocol kesehatan masih sangat minim diterapkan di lingkungan dusun tersebut. Untuk itu diperlukan adanya penguatan edukasi dan sosialisasi bagi masyarakat akan cara pencegahan dan penanganan Covid-19. Penguatan tersebut sebagai upaya preventif dalam menekan penyebaran penularan Covid-19.

Salah satu bentuk kegiatan yang dapat dilaksanakan adalah dengan melakukan menyampaikan informasi lansung kepada masyarakat, pembuatan percontohan cuci tangan bagi warga masyarakat dan melakukan pemasangan poster stiker yang informatif dan mudah 
dipahami oleh masyarakat. Harapan dengan adanya kegiatan tersebut dapat membantu pemerintah dalam mencegah penyebaran Covid-19 dan menjadi pengingat kepada masyarakat untuk senantiasa menjaga kesehatan dan melakukan perilaku pola hidup bersih dan sehat. Selain itu, serangkaian dengan pelaksanaan kegiatan ini, dilaksanakan juga survey tingkat pengatuhan masyarakat tentang Covid-19 dan perilaku masyarakat akan pencegahan Covid-19. Dengan adanya hasil survey tersebut, diharapkan dapat menjadi informasi awal sebagai saran dan masukan bagi pemangku kepentingan setempat dalam upaya pencegahan penularah virus Covid-19.

Dusun Mbomba I Desa Gheo Ghoma Kabupaten Ende adalah Salah satu dusun dari Desa Gheo Ghoma yang terletak di Kecamatan Ende Utara, Kabupaten Ende,Provinsi Nusa Tenggara Timur, Indonesia. Dusun ini memliki 3 RT, yang berbatasan lansung dengan Dusun Mbomba II dan Dusun Nuarengo Desa Gheo Ghoma. Kehidupan perekonomian dan sosial masyarakat Dusun Mbomba I Desa Gheo Ghoma mengalami dampak juga akan adanya pembatasan social. Sebagian besar mata pencaharian warga setempat adalah berdagang. Mayoritas penduduk Desa Gheo Ghoma beragama Katolik. hal ini dibuktikan dengan adanya fasilitas gereja dan tidak adanya tempat ibadah agama lain. Dari segi tingkat pendidikan masyarakat Dusun Mbomba I Desa Gheo Ghoma juga tergolong rendah, hal ini dapat dilihat dari tingkat pendidikan masyarakat yang sebagian besar belum memenuhi pendidikan Sekolah Menengah Atas. Dari segi kebersihan dan sanitasi nampak sudah cukup baik, banyak rumah warga yang sudah layak huni dengan memiliki MCK masing-masing di setiap rumah.

Demografi wilayah Dusun Mbomba I Desa Gheo Ghoma sebagai berikut:

a. Jumlah Kepala Keluarga : $110 \mathrm{KK}$

b. Jumlah Penduduk : 377 Jiwa dengan jenis kelamin laki-laki sebanyak 176 Orang dan perempuan 201 Orang

Adapun sarana dan prasarana yang terdapat di Desa Gheo Ghoma antara lain : Sekolah Dasar, Gereja Lapangan dan Posyandu/Poskesdes. Berdasarkan hasil dari pengamatan di lapangan telah ditemukan beberapa masalah dari masyarakat di wilayah tersebut yaitu:

1. Masih kurangnya kesadaran masyarakat untuk selalu mematuhi protokol kesehatan dalam rangka pencegahan penularan Covid-19.

2. Masih kurangnya kesadaran masyarakat untuk menjaga kesehatan sebagai upaya untuk menjaga imunitas tubuh terhadap Covid-19.

3. Masih kurangnya pengetahuan masyarakat tentang Covid-19 dan vaksinasi sebagai bentuk pencegahan Covid-19

Berdasarkan permasalahan yang ditemukan maka dapat dirumuskan tujuan dan manfaat kegiatan ini sebagai berikut:

1. Meningkatkan kualitas kesehatan masyarakat Dusun Mbomba I Desa Gheo Ghoma Kecematan Ende Utara Kabupaten Ende.

2. Meningkatkan kesadaran masyarakat untuk mematuhi protokol kesehatan dalam rangka pencegahan Covid-19.

3. Membantu program pemerintah dalam memutus rantai penyebaran Covid-19.

4. Meningkatkan kesadaran masyarakat akan pentingnya menjaga imunitas tubuh dan pola hidup sehat.

\section{METODE PELAKSANAAN}

Berdasarkan hasil observasi dan diskusi dengan Kepada Desa Gheo Ghoma dan Kepala Dusun Mbomba I, RW dan RT didapatkan bahwa warga sekitar masih kurang dalam kesadaran mematuhi protokol kesehatan dalam pencegahan Covid-19. Diharapkan dengan adanya kegiatan pengabdian masyarakat yang dilaksanakan ini mampu mengajak masyarakat 
khususnya yang berada di Dusun Mbomba I Desa Gheo Ghoma Kecematan Ende Utara Kabupaten Ende lebih sadar akan pentingnya protokol kesehatan Covid-19 yaitu, 5M (menggunakan masker,mencuci tangan, menjaga jarak, menjauhi kerumunan, mengurangi mobilitas).

Kegiatan pengabdian masyarakat ini dilaksanakan selama 2 minggu mengikuti jadwal Praktik Kerja Lapangan Keperawatan Komunitas mahasiswa Prodi D III Keperawatan Ende Poltekkes Kemenkes Kupang yaitu dari tanggal 26 April 2021 hingga 08 Mei 2021. Kelompok sasaran di sini adalah seluruh masyarakat Dusun Mbomba I Desa Gheo Ghoma mulai dari RT 01 sampai dengan RT 03, baik laki-laki, perempuan, ibu-ibu dan bapak-bapak kisaran usia 17-50 tahun (usia produktif) maupun usia lanjut usia > 60 tahun. Metode kegiatan yang dipakai adalah metode langsung. Metode langsung yaitu dengan langsung turun ke lapangan menghampiri tiaptiap rumah warga berkoordinasi dengan Satgas Covid-19 desa dan memberikan informasi lansung kepada masyarakat dengan pertemuan di ruang terbuka dengan pelaksanaan protocol kesehatan Covid-19 yang ketat, kegiatan lainnya dengan pembuatan percontohan cuci tangan bagi warga masyarakat dan pemasangan poster stiker tentang informasi pencegahan Covid-19. Program kegiatan yang dilaksanakan telah disesuaikan dengan masalah dan kondisi masyarakat di Dusun Mbomba I Desa Gheo Ghoma Kecematan Ende Utara Kabupaten Ende.

Kegiatan ini dengan cara sosialisasi ceramah atau penyuluhan dengan pengumpulan warga di lingkungan sekitar warga masyarakat dan dilakukan juga di lokasi tingkat sekolah dasar untuk memberikan pemahanan dan edukasi tentang cara pencegahan dan penanganan penyebaran Covid-19. Adapun beberapa kegiatan yang dilaksanakan antara lain sebagai berikut:

1. Meningkatkan pengetahuan masyarakat dengan memberikan edukasi dan informasi lansung disertai pembagian leaflet dan poster tentang pencegahan Covid-19 agar masyarakat tahu akan pentingnya mematuhi protokol kesehatan.

2. Senantiasa mengingatkan masyarakat untuk selalu mencuci tangan dengan melakukan pembuatan sarana percontohan cuci tangan bagi warga masyarakat

3. Membagikan masker agar kesadaran masyarakat terhadap Covid-19 dan protokol kesehatan lebih meningkat.

4. Mengajak masyarakat untuk meningkatkan daya tahan tubuh dan pola hidup sehat serta memberikan penjelasan kepada masyarakat tentang pentingnya vaksinasi sebagai bentuk pencegahan Covid-19.

5. Mengetahui tingkat pengetahuan dan kepatuhan masyarakat akan penerapan Covid-19 dengan menggunakan instrument pnegetahuan dan kepatuhan akan Covid-19.

Kegiatan pertama yang dilaksanakan adalah memberikan informasi dan edukasi lansung dan pembagian leaflet. Salah satu bentuk promosi untuk meningkatkan kesadaran masyarakat terhadap Covid-19 adalah dengan pembagian leaflet dan menjelaskan isi leaflet. Kegiatan ini dimulai pada pagi hari pukul 08.00 WITA. Pertama-tama, Tim Pelaksana datang ke kantor desa untuk meminta izin kegiatan. Lalu dengan berkoordinasi dengan SATGAS Covid-19 di Desa Tersebut beserta dengan kepala Dusun Mbomba I untuk mengundang masyarakat untuk berpartisipasi mengikuti pertemuan terbuka dengan protocol kesehatan tentang pemberian informasi dan edukasi ke masyarakat serta diikuti dengan pembagian leaflet, selain itu kegiatan pemberian informasi dan edukasi ini juga dilakukan ke siswa dan siswi di tingkat Sekolah Dasar dengan sebelumnya telah meminta izin ke kepala sekolah dan guru. Pada saat membagikan leaflet Tim Pelaksana menjelaskan apa itu virus Corona, bagaimana cara penularannya, bagaimana cara pencegahannya, apa itu vaksinasi dan manfaatnya, cara ganti pakaian yang benar agar terhindar dari virus Corona, dan cara membersihkan tubuh dan pakaian yang benar sesuai protokol kesehatan, dan yang paling penting mematuhi protokol kesehatan 3M serta cara mejaga tubuh agar tetap sehat. Bentuk penyuluhan dan edukasi ini juga melibatkan kegiatan diskusi tentang permasalahan dalam perilaku masyarakat Desa Gheo Ghoma khususnya Dusun Mbomba I terkait pencegahan penularan virus Covid-19, serta berdiskusi untuk mendapatkan solusi dari permasalahan yang dialami. 
Kegiatan kedua yang dilaksanakan adalah dengan melakukan kegiatan pembuatan sarana percontohan cuci tangan bagi masyarakat sehingga masyarakat lebih mudah untuk selalu mengingat melaksanakan protocol kesehatan cuci tangan dan sebagai contoh untuk membiasakan perilaku positif pada masyarakat di Dusun Mbomba I Desa Gheo Ghoma.

Kegiatan ketiga yaitu pembagian masker kepada masyarakat dan siswa siswi sekolah dasar. Upaya tersebut sebagai salah satu cara untuk meningkatkan kesadaran masyarakat terhadap Covid-19 agar warga dapat mematuhi protokol kesehatan. Kegiatan dimulai pada pagi hari pukul 08.00 WITA hingga selesai. Kami memulai dengan pembagian masker ke tiap-tiap rumah dan pendudukan masyarakat serta siswa siswi sekolah dasar yang berada di Desa Gheo Ghoma Kabupaten Ende.

Kegiatan keempat adalah penyebaran leaflet dan poster ke rumah-rumah penduduk masyarakat dusun Mbomba I Desa Gheo Ghoma. Kegiatan ini bertujuan agar seluruh warga mendapatkan informasi yang mudah, jelas dan lengkap tentang cara-cara pencegahan Covid-19.

Kegiatan terakhir yaitu pasca kegiatan dilakukan evaluasi kegiatan terutama selama kegiatan pengabdian masyarakat berlangsung. Pada tahap terakhir ini dilakukan penyebaran kuesioner terkait evaluasi/penilaian tingkat pengetahuan dan kepatuhan masyarakat tentang penerapan protocol Covid-19 dan apakah sudah sesuai dengan tujuan dan kebutuhan masyarakat Desa Gheo Ghoma terkhusus Dusun Mbomba I. Selain itu, responden atau masyarakat sangat mengharapkan kegiatan pendampingan kedepannya agar dapat bersama memajukan masyarakat sekitar khususnya masyarakat Desa Gheo Ghoma Kabupaten Ende.

\section{HASIL DAN PEMBAHASAN}

Dalam pelaksanaan kegiatan pengabdian masyarakat ini secara keseluruhan berjalan dengan baik dan lancar. Faktor yang sangat penting dalam membantu kelancaran seluruh kegiatan adalah adanya dukungan serta partisipasi warga masyarakat Dusun Mbomba I Desa Gheo Ghoma yang sangat antusias dan ramah terhadap Tim Pelaksana Kegiatan. Adanya dukungan penuh dan kerja sama dari mitra yaitu perangkat desa seperti, Kepala Desa Gheo Ghoma, Kepala Babinkamtibmas, Kepala Babinsa, Kepada Dusun, Ketua RW, Ketua RT, tokoh masyarakat, dan perangkat desa lainnya juga sangat membantu terlaksananya kegiatan ini. Keberlansungan kegiatan ini mendapatkan respon yang positif dari masyarakat yang tercermin dengan sikap ramah dan antusias nya masyarakat terhadap kegiatan dan tim Pelaksana.

Hasil dari kegiatan pengabdian ini adalah bertambahnya pengetahuan masyarakat tentang pencegahan Covid-19 melalui pemberian edukasi dan informasi lansung kepada masyarakat disertai pembagian leaflet dan poster, edukasi dilaksanakan dengan penjelasan melalui persentasi materi, video dan diskusi secara langsung kepada masyarakat. Pada awalnya masyarakat kurang memiliki kesadaran terhadap Covid-19, terlihat dengan masyarakat yang tidak menerapkan protokol kesehatan. Dari hasil wawancara dengan perangkat desa bahwa kurangnya minat tersebut juga didasarkan tingginya focus masyarakat hanya mencari pemenuhan kebutuhan setiap hari untuk keluarga dan belum adanya kasus terindikasi Covid-19 di Desa Gheo Ghoma. Prinsip masyarakat meyakini bahwa jika tidak bekerja/berusaha maka dia tidak akan bisa makan atau memenuhi kebutuhan hidupnya dan keluarganya.oleh sebab itu, masyarakat akan berupaya untuk bekerja untuk mendapatkan penghasilan walaupan kadang tidak focus dalam penerapan protocol pencegahan Covid-19 (Kuntardi, 2021).

Dasar tersebut sehingga membuat banyak dari masyarakat yang belum memahami tentang bahaya Covid-19. Oleh karena itu, kami melaksanakan edukasi pencegahan dan memberikan informasi terkait penerapan penanganan Covid-19 disertai pembuatan sarana percontohan cuci tangan, pembagian leaflet, poster stiker, masker, dan turun lansung menjelaskan kepada masyarakat cara penularan Covid-19 dan cara pencegahannya. Indikator keberhasilan kegiatan ini adalah warga antusias saat mendengarkan penjelasan kemudian mengajukan pertanyaan dan didapatkannya hasil evaluasi pengetahuan masyarakat yang cukup baik akan Covid-19 dan hasil evaluasi perilaku masyarakat akan pencegahan Covid-19. Warga 
dan siswa siswi di tingkat sekolah dasar juga senang menerima masker dan langsung memakai masker tersebut, setelah membagikan masker, tim pelaksana juga lansung mengajarkan cara menggunakan masker yang baik dan benar kepada masyarakat. Warga senang dan banyak bertanya tentang cara menjaga kesehatan di masa pandemic saat ini, termasuk manfaat dari vaksinasi Covid-19. Indikator lainnya adalah adanya adanya feedback yang baik oleh perangkat desa dan masyarakat setempat akan kegiatan pengabdian ini. Masyarakat diibaratkan sebagai sistem sosial yang didalamnya terdiri dari bagian-bagian maupun elemen yang saling berkaitan, saling mempengaruhi, dan menyatu dalam menciptakan dukungan satu sama lain demi kebaikan lingkungan (Kuntardi, 2021).

Sosialisasi, edukasi dan pemberian informasi merupakan program utama kami. Diharapkan dengan adanya edukasi lansung dan menggunakan media poster stiker maupun leaflet yang menonjolkan prosedur pencegahan Covid-19 dengan protokol kesehatan sangat memudahkan masyarakat dalam memahami dan meningkatkan kesadaran masyarakat agar senantiasa menerapkan protokol kesehatan sehingga dapat memutus rantai penularan Covid-19 di Kabupaten Ende terkhusus di Desa Gheo Ghoma.

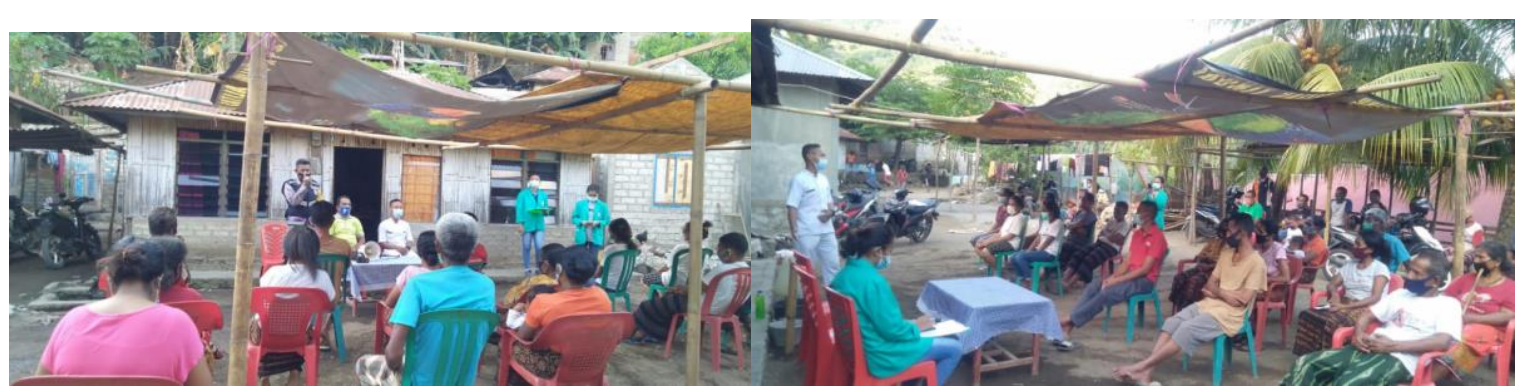

Gambar 1. Sosialisasi dan edukasi kepada masyarakat

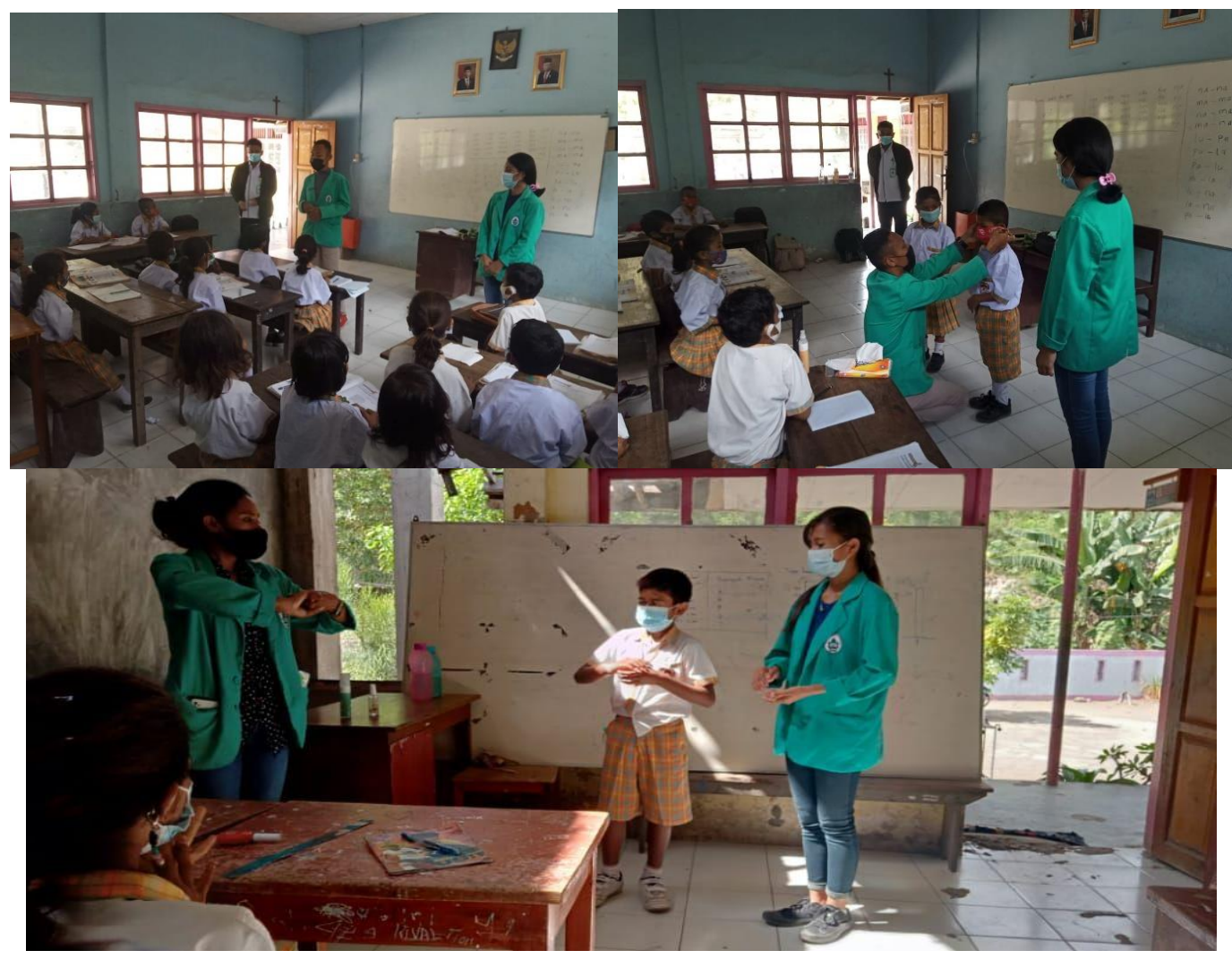

Gambar 2. Sosialisasi dan edukasi siswa siswi Sekolah Dasar 


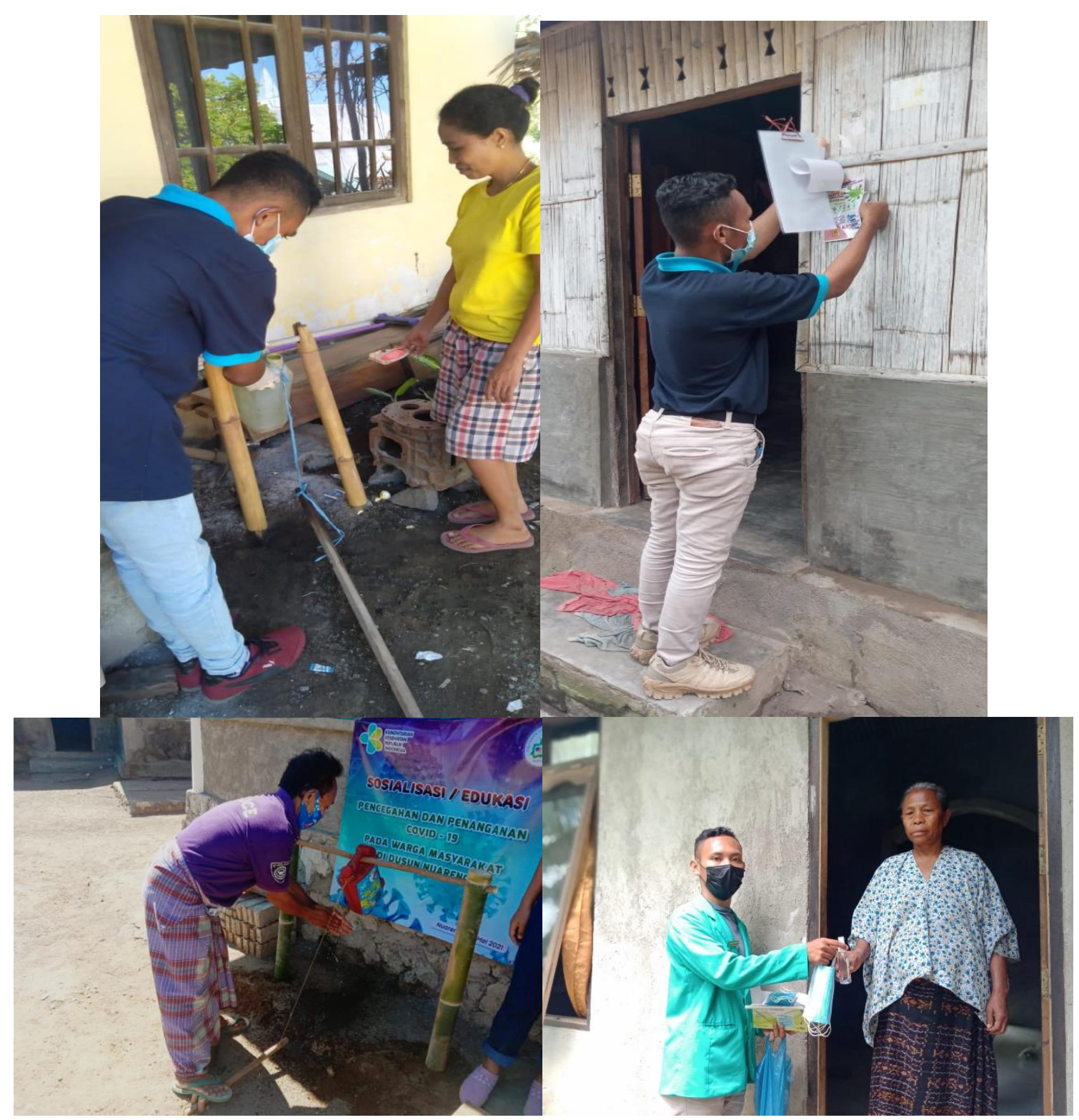

Gambar 3. Pembuatan percontohan sarana cuci tangan bagi mmasyarakat, pembagian masker, dan pemasangan poster stiker informasi pencegahan Covid-19

Pada kegiatan ini juga dilakukan evaluasi terhadap kegiatan abdimas. Ada beberapa pernyataan yang diajukan terkait pelaksanaan kegiatan. Secara keseluruhan, hasil pengetahuan dan perilaku masyarakat pada kegiatan abdimas ini sudah sebagaian besar memiliki pengetahuan cukup baik dan hasil perilaku pencegahan Covid-19 cukup baik. Menurut pandangan Putra \& Manalu (2020), juga mengemukakan bahwa upaya pemutusan mata rantai penyebaran Covid-19 memang memerlukan pemahaman dan pengetahuan yang baik dari seluruh elemen masyarakat. Pengetahuan yaitu sesuatu yang ditangkap melalui panca indera yakni penglihatan, pendengaran, penciuman, perabaan dan perasaan terhadap suatu obyek sehingga mampu dimengerti dan dipahami seseorang. Hasil evaluasi dapat dilihat pada gambar 3 berikut. 


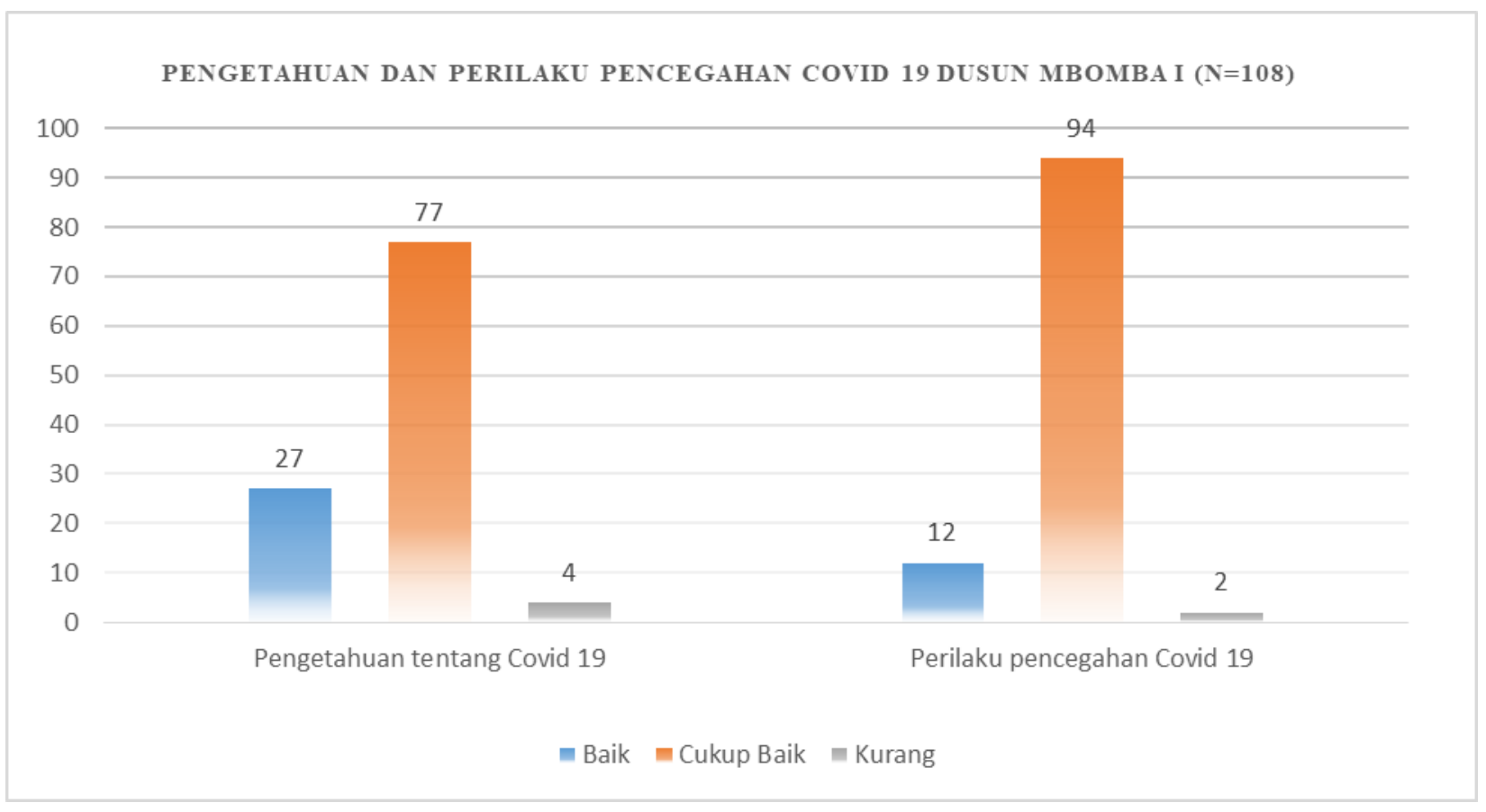

Gambar 4. Grafik evaluasi pengetahuan dan perilaku masyarakat tentang pencegahan Covid-19

Masyarakat mengharapkan kegiatan pendampingan kedepannya agar dapat bersama memajukan masyarakat sekitar khususnya masyarakat Desa Gheo Ghoma Kecamatan Ende Utara Kabupaten Ende. Adanya sikap dan dorongan positif dari perangkat desa dan tokoh masyarakat untuk mengajak dan menghimbau warga masyarakat melakukan upaya pencegahan dan penanggulangan dampak pandemi menjadi dorongan positif. Selain itu dengan memberi contoh lain dari tindakan pencegahan yaitu menerapkan selalu tindakan perilaku hidup bersih dan sehat. Perilaku perangkat desa dan para tokoh masyarakat itu sekaligus menggambarkan peran mereka dalam upaya pencegahan dan penanggulangan pandemi; yang sekaligus juga mendorong tumbuhnya kemandirian warga masyarakat desa di dalam merespon pandemi Covid-19 (Rosidin et al., 2020).

Sampai dengan saat ini belum ditemukan obat yang benar-benar mampu menyembuhkan COVID-19 sehingga diperlukan upaya pencegahan dari setiap individu termasuk untuk berpartisipasi dalam kegiatan vaksinasi untuk menekan angka kejadian Covid19. Menghadapi pandemi ini beberapa upaya untuk mencegah penyebaran covid 19 yang dapat dilakukan yaitu deteksi dini dan melakukan isolasi, menerapkan protokol kesehatan, menerapkan personal higiene, sering mencuci tangan, melakukan desinfeksi, menggunakan alat pelindung diri, dan mempersiapkan daya tahan tubuh yang baik dengan mengonsumsi vitamin, berolahraga ringan dan melaksanakan vaksinasi. Saat ini Pemerintah berupaya secara maksimal memutus rantai penularan dalam mengatasi Covid-19 demi menyelamatkan masyarakat Indonesia. Adapun upaya yang dilakukan antara lain memberikan edukasi tentang bahaya virus Corona (Covid-19), melakukan pembatasan social di setiap daerah secara ketat, selalu merekomendasikan untuk menerapkan protokol kesehatan, meningkatkan kualitas hidup pasien menjadi lebih baik, bahkan memberikan bantuan kepada masyarakat yang terdampak agar memiliki kesehatan yang lebih baik dengan menyediakan makanan yang bergizi (Kemenkes RI, 2021a).

Diperlukan koordinasi sinergis dari para akademisi, tenaga kesehatan, dan pemerintah yang memiliki peran penting untuk pencegahan penyebaran Covid-19. Hal ini dikarenakan masih banyak masyarakat, terutama di tingkat desa yang kurang peduli akan hadirnya Covid-19 itu sendiri sehingga kita harus selalu berusaha secara komprehensif memberikan edukasi dan mengubah pola pikir masyarakat guna untuk saling menjaga kesehatannya masing-masing dan membangun perekonomian pemerintah dan social yang lebih baik lagi. Jika pengetahuan 
masyarakat tentang Covid19 sudah terpenuhi, maka dengan sendirinya masyarakat akan mengikuti protokol kesehatan dengan baik, harapan untuk selalu menjaga imunitas tubuh dengan mengonsumsi vitamin dan melaksanakan vaksinasi (Kemenkes RI, 2021b).

\section{SIMPULAN DAN TINDAK LANJUT}

Dari penjelasan di atas, antusias dan tingkat perilaku kepatuhan masyarakat khususnya Dusun Mbomba I Desa Gheo Ghoma Kabupaten Ende, yang diwakili oleh seluruh aparatur desa, kepala babinsa, kepala bainkamtibmas, penyuluh kesehatan, dan RW, RT dalam meningkatkan pengetahuan tentang Covid-19 dan menerapkan protokol kesehatan adalah sebagai langkah penting dalam pencegahan penularan virus Covid-19. Kegiatan pengabdian masyarakat ini mempunyai tiga sasaran utama yaitu: mahasiswa, masyarakat bersama pemerintah, dan perguruan tinggi yang bertujuan untuk meningkatkan kualitas sumber daya manusia terutama dalam peningkatan kesadaran masyarakat terhadap Covid-19.

Desa Gheo Ghoma memiliki permasalahan yaitu kurangnya kesadaran masyarakat terhadap penyakit Covid-19 yang sedang melanda dunia hingga saat ini. Permasalahan tersebut adalah hasil dari observasi dan diskusi dengan Kepala Desa, Kepala Dusun, Ketua RW, Ketua RT dan beberapa tokoh masyarakat. Diharapkan dengan adanya kegiatan pengabdian ini dapat meningkatkan pengetahuan masyarakat, merubah perilaku serta menumbuhkan kesadaran masyarakat terhadap Covid-19. Kegiatan berupa edukasi pencegahan dan penanganan covid-19 pada masyarakat serta pembagian masker, poster, dan leafleat agar seluruh masyarakat khususnya warga Dusun Mbomba I Desa Gheo Ghoma dapat meningkatkan pengetahuan dan merubah perilaku kearah yang lebih positif dan dapat terlindungi dari penularan Covid-19. Kegiatan edukasi dan sosialisasi pencegahan penularan virus Covid-19 menjadi hal sederhana yang perlu dilakukan secara konsisten, agar dapat membangun kepedulian masyarakat dalam menjaga kesehatan, melakukan pola hidup bersih dan sehat, terutama dalam masa pandemic saat ini. Kegiatan ini dapat terlaksana dengan baik dan cukup berhasil berkat dukungan dari semua pihak baik rekan-rekan tim pelaksana, mahasiswa, masyarakat dan perangkat pemerintahan Desa Gheo Ghoma Kabupaten Ende.

\section{DAFTAR PUSTAKA}

Amalia, L., \& Hiola, F. (2020). Analisis gejala klinis dan peningkatan kekebalan tubuh untuk mencegah penyakit covid-19. Jambura Journal of Health Sciences and Research, 2(2), 71-76.

Han, Q., Lin, Q., Rci, O., \& You, L. (2020). Uncertainties about the transmission routes of 2019 novel coronavirus. Influenza Other Respi Viruses, 14, 470-471. https://doi.org/10.1016/j.jhin.2020.01.022

Hanoatubun, S. (2020). Dampak Covid-19 terhadap Prekonomian Indonesia. EduPsyCouns: Journal of Education, Psychology and Counseling, 2(1), 146-153.

Kemenkes RI. (2021a). Dukungan Kesmas Di Masa Pandemi Covid 19. In Warta Kesmas Kementerian Kesehatan Republik Indonesia (01 ed.). Warta Kesmas Kemenkes RI.

Kemenkes RI. (2021b). Question (Faq) Pelaksanaan Vaksinasi Covid-. https://kesmas.kemkes.go.id/assetspdf

Kemenkes RI Dirjen P2P. (2021). Keputusan Direktur Jenderal Pencegahan dan Pengendalian Penyakit Nomor Hk.02.02/4/1/2021 tentang Petunjuk Teknis Pelaksanaan Vaksinasi dalam Rangka Penanggulangan Pandemi Corona Virus Disease 2019 (COVID-19). Kementerian Kesehatan RI, 4247608(021), 114. https://www.kemkes.go.id/article/view/19093000001/penyakit-jantung-penyebabkematian-terbanyak-ke-2-di-indonesia.html

Kuntardi, D. V. S. (2021). Dinamika Sistem Sosial Masyarakat Pedesaan di Masa Pandemi Covid19. Ideas: Jurnal Pendidikan, Sosial, Dan Budaya, 7(1), 1-10.

Pemprov NTT. (2020). Pergub NTT Nomor 26 tentang pedoman tatanan normal baru di Provinsi 
NTT. https://peraturan.bpk.go.id/Home/Details/142525/pergub-prov-nusa-tenggaratimur-no-26-tahun-2

Putra, W. I. Y., \& Manalu, N. V. (2020). Tingkat Pengetahuan Dengan Perilaku Warga Dalam Menjalankan Protokol Kesehatan di Masa New Normal Pandemi Corona. Community of Publishing In Nursing (COPING), 8(4), 366-373.

Rosidin, U., Rahayuwati, L., \& Herawati, E. (2020). Perilaku dan peran tokoh masyarakat dalam pencegahan dan penanggulangan pandemi covid-19 di Desa Jayaraga, Kabupaten Garut. Umbara, 5(1), 42-50.

Satuan Tugas Penanganan COVID-19. (2021). Peta Sebaran / Covid19.go.id. https://covid19.go.id/peta-sebaran

Wang, D., Hu, B., Hu, C., Zhu, F., Liu, X., Zhang, J., Wang, B., Xiang, H., Cheng, Z., Xiong, Y., Zhao, Y., Li, Y., Wang, X., \& Peng, Z. (2020). Clinical Characteristics of 138 Hospitalized Patients With 2019 Novel Coronavirus-Infected Pneumonia in Wuhan, China JAMA | Original Investigation | CARING FOR THE CRITICALLY ILL PATIENT. JAMA, 323(11), 1061-1069. https://doi.org/10.1001/jama.2020.1585 